MPD 推進機における非平衡 2 流体モテルの 1 次元理論*1

\title{
One-Dimensional Theory Based on a Two-Fluid Nonequilibrium Plasma Model in MPD Thrusters
}

\author{
小林修*2,3 - 小紫 公也*2 \\ Osamu Kobayashi, Kimiya KomURASAKI \\ 藤 原 俊 隆*2 \\ and Toshi Fujiwara
}

Key Words : Electric Propulsion, MPD Thruster, Nonequilibrium Ionization, Two-Fluid Model

\begin{abstract}
A numerical analysis for a modeled plasma flow in an MPD thruster has been done, including nonequilibrium ionization/recombination processes of the propellant gas. According to the existing studies on MPD thrusters, current density distribution in a discharge chamber is strongly influenced by the nonequilibrium ionization processes. In order to determine the ionization fraction at the inlet of chamber, backstream of plasma from the arc region is taken into account. In this study, the flowfield based on this nonequilibrium and two-fluid model is theoretically analyzed.
\end{abstract}

記 号

$a$ : 音速

$B:$ 磁束密度

$E:$ 電界強度

$h:$ 総エンタルピー

$I ：$ 荷電粒子と中性粒子の相互作用

$J:$ 全放電電流

$j:$ 電流密度

$k$ : Boltzmann 係数

$L$ : 電極長

$m:$ 質量

$\dot{m}$ : 推進剤流量

$n$ : 数密度

$p:$ 圧力

$Q:$ 董突断面積

$T:$ 温度

$u:$ 流れの平均速度

$v:$ 熱速度

$x$ : 位置

"1 平成 6 年 4 月 11 日原稿受理

*2 名古屋大学工学研究科航空宇宙工学尃攻

*3 現在：富士重工業(株)

$$
\begin{aligned}
& \alpha: \text { 電離度 } \\
& \gamma: \text { 比熱比 } \\
& \varepsilon: \text { 電離エネルギー } \\
& \nu: \text { 衝突周波数 } \\
& \sigma: \text { 電気伝導度 } \\
& \text { 添え字 } \\
& \mathrm{e}: \text { 電子 } \\
& \mathrm{i}: \text { イン } \\
& \mathrm{n}: \text { 中性粒子 } \\
& \mathrm{p}: \text { プラズマ } \\
& *: \text { 音速点 } \\
& 0: u_{\mathrm{p}}=0 \text { の点 } \\
& \text { A : } u_{\mathrm{p}}=0 \text { の点から音速点までの積分値 } \\
& \quad \quad \text { 1. は し } \text { に }
\end{aligned}
$$

MPD 推進機の放電室における電流密度分布は, 推 進機の性能と密接に関係しており.その電流分布のメ カニズムを解析的に明らかにすることは, 性能向上を 図る上で大変重要である，これまでの解析では，放電 室内の電流分布に対して電極形状や閉塞条件が与える 影響を調へるために，完全電離プラスマが仮定される ことが多かった1,21 一方実験によれば，推進剤が単 原子分子気体か多原子分子気体加によって電流分布に 大きな違いがみられ，推進剤の電離，解離過程が電流 分布に大きな影響を及ほしているのではないか、とい う指摘がなされていだ) 例えば，推進成が水素やア ンモニアの場合には，アルコンンの場合に比べて下流に 電流が分布する。これは多原子分子の場合, 電離反応 に先立って解離反応が起こるため, 電離度の上昇が遅 れるのだと考えられる。そこで, 非平衡な電離，再結 合反応を考虑した解析が盛んに行われるようになっ $た^{4 \sim 7)}$.

しかし, 非平衡反応モデルにおいて電極入口におけ 
る電離度をどのように与えるかは難しい問題である． 電離度を 0 と与えると, その下流においてまったく電 離が起こらない そのため実際の計算では, 電極入口 で適当な電離度を人為的に与えているのが現状であ る. 特にこれまでの非平衡反応モデルでは，わずか数 $\mathrm{cm}$ の放電室内に数 $\mathrm{kA}$ から数百 $\mathrm{kA}$ の大電流を流す ために，電極入口でかなり大きな電䧹度を仮定する必 要があった，最近になって，電極入口で電離反応が活 発になるメカニスムが幾つか提案されているが、棌， 本研究ではこのメカニスムの 1 つとして，圧力勾配に よる荷電粒子の上流への逆流に注目し，1 次元の数值 解析を行った。この荷電粒子の逆流をモデル化するに は，荷電粒子の流れと中性粒子の流れを別々に扱う必 要があるため，2 流体モデルを導入した。

\section{2. モ $ル$ 化}

2.1 非平衡 2 流体モデル 電極入口における電離 度はどのように決まるのかを考えてみる，一般に活発 な電離反庍が起こるには，電子の存在が不可欠であ る.そこで, 放電領域よりも上流に電子が存在するメ カニスムとして考えられるのが，第 1 図に示すような アーク放電領域からの荷電粒子の逆流である．放電室 内に流入した推進剤は、アーク放電で急激に電離, 加 熱されて高温, 高密度のプラズマを生じ，その一部が 圧力勾配によって電極入口方向に逆流する。

電子の質量はイオンや中性粒子に比へて小さいた め. 電子は圧力勾配によって大きな加速を受ける．し かし電子とイオンの密度に差が生じると，それを打ち 消すように電界が生じ，その結果イオンは加速され， 電子は減速され，結局イオンと電子は同一の流れ速度

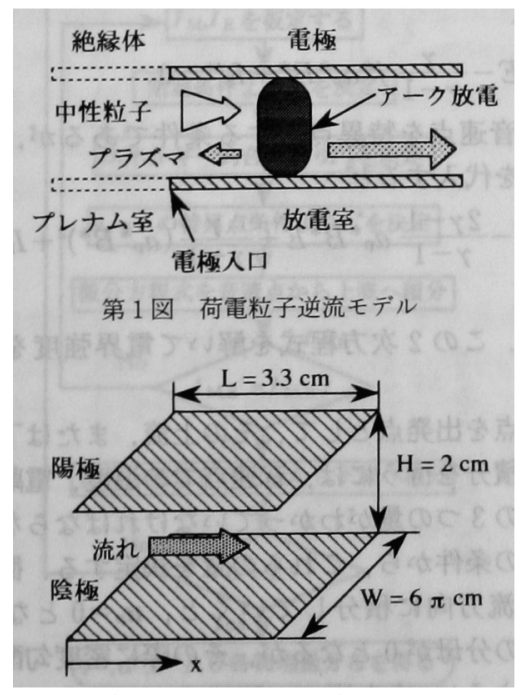

第 2 図 1 次元 MPD スラスター
を持つ.この荷電粒子の逆流を，1流体モデル，すな わち荷電粒子と中性粒子の速度も同一であると仮定し たモデル4ー6)で扱ちうとすると，連続の式を解くこと ができない，そこで本研究では，荷電粒子と中性粒子 の速度を分離した，非平衡 2 流体モデルを導入する。

2.2 仮定 以下のような仮定の下で解析を行う.

1) 第 2 図に示すような平行平板電極を考え, 定常 1 次元問題とする。

2) 推進用はアルコンで, 流机の成分は $\mathrm{Ar}, \mathrm{Ar}^{+}$, $\mathrm{e}^{-の 3}$ 種である。

$3)$ プラズマは準中性とする. $\left(n_{\mathrm{e}}=n_{\mathrm{l}} \equiv n_{\mathrm{p}}\right)$

4) 荷電粒子の流れと中性粒子の流れを別々に考 え, 中性粒子の速度, 温度は放電室内で一定と する。

5 ) 電子励起過程や粘性, 熱伝導等の輸送過程は無 視する。

2.3 基礎方程式 荷電粒子の連続の式は, 次のよ うに表される：

$$
\frac{d}{d x}\left(n_{\mathrm{p}} u_{\mathrm{p}}\right)=\dot{n}_{\mathrm{p}}
$$

右辺の生成項は, 以下の様な電子衝突電離と, その逆 過程である 3 体再結合を考え

$$
\mathrm{Ar}+\mathrm{e}^{-}=\mathrm{Ar}^{+}+\mathrm{e}^{-}+\mathrm{e}^{-}
$$

生成率を次の様に表す：

$$
\dot{n}_{\mathrm{p}}=k_{\mathrm{f}} n_{\mathrm{p}} n_{\mathrm{n}}-k_{\mathrm{b}} n_{\mathrm{p}}{ }^{3}
$$

ここで $k_{\mathrm{f}}$ と $k_{\mathrm{b}}$ は，それぞれ電離と再結合に対する反 応速度定数であり，荷電粒子の温度を用い，MKS 単 位系によって以下のように与えられるる,

$$
\begin{aligned}
& k_{\mathrm{f}}=\frac{76.8}{T_{\mathrm{p}}{ }^{3}} \exp \left(-\frac{\varepsilon}{k T_{\mathrm{p}}}\right) \\
& k_{\mathrm{b}}=4.0 \times 10^{-21} T_{\mathrm{p}}{ }^{-9 / 2}
\end{aligned}
$$

荷電粒子の運動方程式は次のように表される：

$$
\frac{d}{d x}\left(m_{1} n_{\mathrm{p}} u_{\mathrm{p}}^{2}\right)=-\frac{d p_{\mathrm{p}}}{d x}+j B+I_{\mathrm{M}}
$$

これは電子の運動方程式 :

$$
\frac{d}{d x}\left(m_{\mathrm{e}} n_{\mathrm{e}} u_{\mathrm{e}}^{2}\right)=-\frac{d p_{\mathrm{e}}}{d x}-e n_{\mathrm{e}} E_{\mathrm{x}}+j B+I_{\mathrm{M}, \mathrm{e}}
$$

とイオンの運動方程式 :

$$
\frac{d}{d x}\left(m_{1} n_{1} u_{1}^{2}\right)=-\frac{d p_{1}}{d x}+e n_{1} E_{x}+I_{M, 1}
$$

を足し合わせ， $m_{1} \gg m_{\mathrm{e}}$ を用いて

$$
m_{\mathrm{e}} n_{\mathrm{e}} u_{\mathrm{e}}^{2}+m_{1} n_{1} u_{1}^{2} \approx m_{1} n_{1} u_{1}^{2}
$$

とすることにより導出される． $p_{\mathrm{p}}$ はプラズマの全压 を表し、プラズマ密度と温度を用いて次のように表さ れる:

$$
\begin{aligned}
p_{\mathrm{p}} & =n_{\mathrm{l}} k T_{\mathrm{I}}+n_{\mathrm{e}} k T_{\mathrm{e}} \\
& =2 n_{\mathrm{p}} k T_{\mathrm{p}}
\end{aligned}
$$

(6)式の右辺第 1 項は圧力勾配による力を表し，第 2 
項はローレンツカを表す。第 3 項は中性粒子との相互 作用により受ける力を表し，次のように定義される：

$$
\begin{aligned}
I_{\mathrm{M}}= & I_{\mathrm{M}, \mathrm{e}}+I_{\mathrm{M}, \mathrm{I}} \\
= & -\frac{m_{1}}{2} n_{\mathrm{p}} \nu_{\mathrm{In}}\left(u_{\mathrm{p}}-u_{\mathrm{n}}\right) \\
& +m_{1} u_{\mathrm{n}} k_{\mathrm{f}} n_{\mathrm{p}} n_{\mathrm{n}}-m_{1} u_{\mathrm{p}} k_{\mathrm{b}} n_{\mathrm{p}}{ }^{3}
\end{aligned}
$$

ここで $\nu_{\text {n }}$ はイオンと中性子の間の衝突頻度で， $\nu_{\text {in }}=$ $Q_{\ln } v_{\mathrm{n}} n_{\mathrm{n}}$ と表される。ただし， $v_{\mathrm{n}}$ はイオンと中性粒 子の相対速度で $v_{\mathrm{in}}=\sqrt{3 k\left(T_{\mathrm{p}}+T_{\mathrm{n}}\right) / m_{1}}$ である。

荷電粒子のエネルギー方程式は，次のように表され る:

$$
\frac{d}{d x}\left(\frac{\gamma}{\gamma-1} p_{\mathrm{p}} u_{\mathrm{p}}+\frac{1}{2} m_{\imath} n_{\mathrm{p}} u_{\mathrm{p}}{ }^{3}\right)=j E-\varepsilon_{1} \dot{n}_{\mathrm{P}}+I_{\mathrm{E}}
$$

これも電子とイオン，それぞれのエネルギー方程式を 足し合わせたものである. 右辺第 1 項は入力エネルギ 一，第 2 項は電離により失われるエネルギー，第 3 項 は中性粒子との相互作用により失われるエネルギーを 表す IEは次のように定義される：

$$
\begin{aligned}
I_{\mathrm{E}}= & -\frac{1}{2} m_{\mathrm{l}} n_{\mathrm{p}} \nu_{\mathrm{in}}\left(u_{\mathrm{p}}-u_{\mathrm{n}}\right) u_{\mathrm{p}} \\
& -n_{\mathrm{p}} k\left(T_{\mathrm{p}}-T_{\mathrm{n}}\right)\left(\frac{3 m_{\mathrm{e}}}{m_{\mathrm{l}}} \nu_{\mathrm{en}}+\frac{3}{4} \nu_{\mathrm{ln}}\right) \\
& +\left(\frac{1}{2} m_{\mathrm{i}} u_{\mathrm{n}}{ }^{2}+\frac{1}{\gamma-1} k T_{\mathrm{n}}\right) k_{\mathrm{f}} n_{\mathrm{p}} n_{\mathrm{n}} \\
& -\left(\frac{1}{2} m_{\mathrm{l}} u_{\mathrm{p}}{ }^{2}+\frac{2}{\gamma-1} k T_{\mathrm{p}}\right) k_{\mathrm{b}} n_{\mathrm{p}}{ }^{3}
\end{aligned}
$$

ここで $\nu_{\mathrm{en}}$ は電子と中性粒子の間の衝突頻度, $\nu_{\mathrm{en}}=$ $Q_{\mathrm{en}} v_{\mathrm{en}} n_{\mathrm{n}}$ で， $v_{\mathrm{en}}$ は電子と中性粒子の相対速度 $v_{\mathrm{en}}=$ $\sqrt{3 k T_{\mathrm{p}} / m_{\mathrm{e}}}$ とする。

中性粒子の連続の式は，速度を一定と仮定して次の ように表される：

$$
\frac{d n_{\mathrm{n}}}{d x}=-\frac{\dot{n}_{\mathrm{p}}}{u_{\mathrm{n}}}
$$

中性粒子は, 速度, 温度とも一定と仮定しているた め, 運動方程式やエネルギー方程式を解く必要はな い.

$$
\begin{gathered}
\text { オームの法則は，次のように表される： } \\
j=\sigma\left(E-u_{\mathrm{p}} B\right)
\end{gathered}
$$

ここで電気伝導度は，電子とイオンの衝突によるもの $\sigma_{\mathrm{c}}$ と電子と中性粒子の衝突によるもの $\sigma_{\mathrm{n}}$ とを考慮 し, 次のように表す

$$
\frac{1}{\sigma}=\frac{1}{\sigma_{\mathrm{c}}}+\frac{1}{\sigma_{\mathrm{n}}}
$$

$\sigma_{\mathrm{c}}, \sigma_{\mathrm{n}}$ は，それぞれ次のように与えられる(10)：

$$
\sigma_{\mathrm{c}}=1.5 \times 10^{-3} T_{\mathrm{p}}{ }^{3 / 2}, \quad \sigma_{\mathrm{n}}=\frac{e^{2} n_{\mathrm{p}}}{m_{\mathrm{e}} \nu_{\mathrm{en}}}
$$

アンペールの法則は，以下のように表される：

$$
\frac{d B}{d x}=-\mu_{0} j
$$

$\mu_{0}$ 㹥真空透磁率であり，一定と仮定する．

\section{3. 計 算 方 法}

\section{1 定常問题における音速点での物理典を決定す} るための条件 基礎方程式のうち, 荷電粒子に対す る 3 保存式 (1)，（6），(12）より，次のような 1 階の 微分方程式が得られる。

$$
\begin{aligned}
\frac{d u_{\mathrm{p}}}{d x}= & \frac{j E-\{\gamma /(\gamma-1)\} j u_{\mathrm{p}} B+I_{\mathrm{E}}^{\prime}}{\{2 \gamma /(\gamma-1)\} n_{\mathrm{p}} k T_{\mathrm{p}}\left(1-u_{\mathrm{p}}{ }^{2} / a_{\mathrm{p}}{ }^{2}\right)} \\
\frac{d n_{\mathrm{p}}}{d x}= & \frac{\dot{n}_{\mathrm{p}}-n_{\mathrm{p}}\left(d u_{\mathrm{p}} / d x\right)}{u_{\mathrm{p}}} \\
\frac{d T_{\mathrm{p}}}{d x}= & -\frac{m_{\mathrm{p}} u_{\mathrm{p}}{ }^{2}+2 k T_{\mathrm{p}}}{2 k n_{\mathrm{p}}} \frac{d n_{\mathrm{p}}}{d x} \\
& -\frac{m_{\mathrm{l}} u_{\mathrm{p}}}{k} \frac{d u_{\mathrm{p}}}{d x}+\frac{1}{2 k n_{\mathrm{p}}}\left(j B+I_{\mathrm{M}}\right)
\end{aligned}
$$

ここで $I_{\mathrm{E}}^{\prime}$ は, 前述の荷電粒子と中性粒子の相互作用 の項 $I_{\mathrm{E}}, I_{\mathrm{M}}$ を含む項であり，次のように表される :

$$
I_{\mathrm{E}}^{\prime}=I_{\mathrm{E}}-\frac{\gamma}{\gamma-1} u_{\mathrm{P}} I_{\mathrm{M}}+\left(\frac{\gamma+1}{\gamma-1} \frac{m_{1} u_{\mathrm{p}}^{2}}{2}-\varepsilon\right) \dot{n}_{\mathrm{p}}
$$

また荷電粒子の音速は次のように定義される：

$$
a_{\mathrm{p}}^{2} \equiv \gamma \frac{2 k T_{\mathrm{p}}}{m_{\mathrm{l}}}
$$

MPD の閉塞条件としては，流体力学的音速点にお いて与えられる条件" ${ }^{11}$ ，磁気音速点において与えら

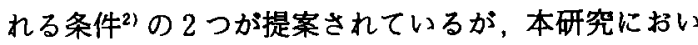
ては前者を用いる， $u_{\mathrm{p}}=a_{\mathrm{p}}$ となる点と， $u_{\mathrm{p}}=0$ とな る点の 2 点で，(19)，(20)式の分母がそれぞれ0とな る。したがってこれらの 2 点で，それぞれの分子もま た 0 となる必要がある．まず $u_{\mathrm{p}}=a_{\mathrm{p}}$ となる点，すな わち音速点では，(21)式の分子が 0 とならなければな らない.

$$
j^{*} E-\frac{\gamma}{\gamma-1} j^{*} a_{\mathrm{p}}{ }^{*} B^{*}+I_{\mathrm{E}}{ }^{*}=0
$$

これは音速点を特異点にする条件であるがここれに (15)式を代入すると

$$
E^{2}-\frac{2 \gamma-1}{\gamma-1} a_{\mathrm{p}}{ }^{*} B^{*} E+\frac{\gamma}{\gamma-1}\left(a_{\mathrm{p}}{ }^{*} B^{*}\right)^{2}+I_{\mathrm{E}}{ }^{*}=0
$$

となる。この 2 次方程式を解いて電界強度を決定す る.

音速点を出発点として，その上流，または下流に向 かって積分を行うには，音速点での温度，電離度，磁 束密度の3つの量がわかっていなければならない。そ こで他の条件から，これらの量を決定する．微分方程 式を上流方向に積分していくと， $u_{\mathrm{p}}=0$ となる点て (20)式の分母が 0 となるが，その際に密度勾配が有限 となるように $\alpha^{*}$ を選ぶ. 同時に，(20)式の分子が 0 
となるように、この点での物理量を決定する。

$$
\frac{2 \gamma}{\gamma-1} n_{\mathrm{p}}{ }^{0} k T_{\mathrm{p}}^{0} \dot{n}_{\mathrm{p}}{ }^{0}-\left(j^{0} E+I_{\mathrm{E}}{ }^{0}\right) n_{\mathrm{p}}{ }^{0}=0
$$

続いて $T^{*}$ を求めるために，第 3 図に示すような音 速点上流域でのエネルギー収支を考える．音速点にお ける総エンタルピーは，

$$
\begin{aligned}
h_{\mathrm{p}}{ }^{*} & =\left(\frac{m_{1} a_{\mathrm{p}}{ }^{* 2}}{2}+\frac{2 \gamma}{\gamma-1} k T_{\mathrm{p}}^{*}\right) n_{\mathrm{p}}{ }^{*} a_{\mathrm{p}}{ }^{*} \\
& =\frac{\gamma(\gamma+1)}{\gamma-1} k T_{\mathrm{p}}^{*} n_{\mathrm{p}}{ }^{*} a_{\mathrm{p}}{ }^{*}
\end{aligned}
$$

と表せる。この上流域てのエネルギー損失としては， 電離反応と，中性粒子とのエネルギー交換によるもの とが考えられる。これらのエネルギー釣合式は

$$
h_{\mathrm{p}}{ }^{*}=\hat{j} E-\epsilon n_{\mathrm{p}}{ }^{*} a_{\mathrm{p}}{ }^{*}-\hat{I}_{\mathrm{E}} E
$$

と表される.ここで $\hat{j}_{1} \hat{I}_{\mathrm{E}}$ はそれぞれ，電極入口から 音速点までに流れた電流，およびその間の中性粒子と のエネルギー交換の積分値である．音速点ての総エン タルピーから荷電粒子の温度を求めることがでる.

最後に，音速点での物理量のうち $B^{*}$ を決定する条
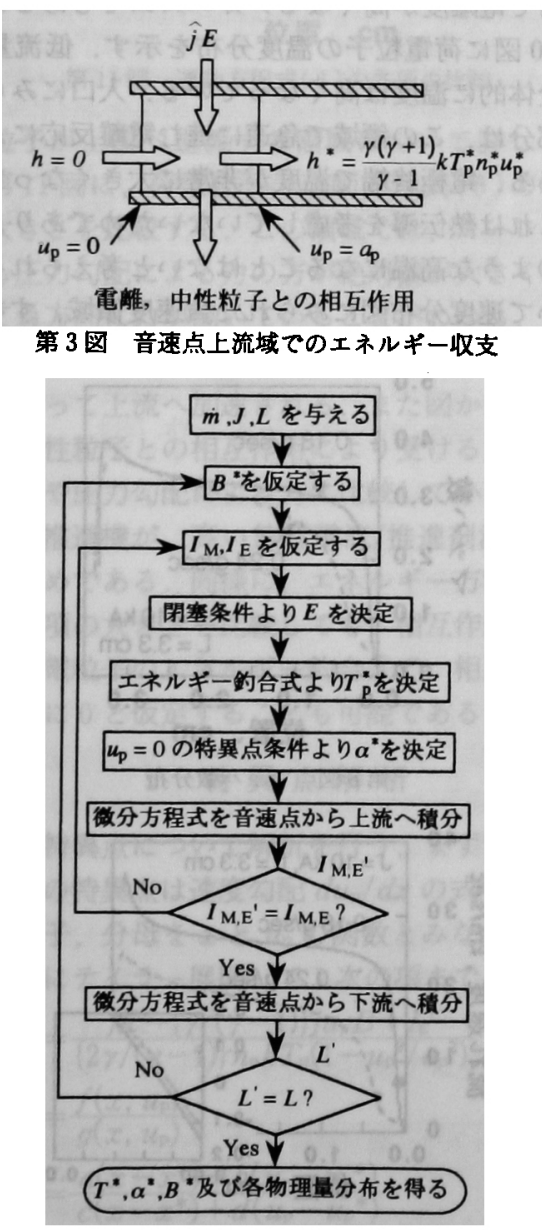

第 4 図計算のフローチャート
件を考える．実際の推進機では電極長は固定されてお り，電極終端て全放電電流が流れ切り，磁束密度は 0 となる，したがって音速点での磁束密度は，電極長を 与えることにより決定される。

3.2 計算手順 計算のフローチャートを第 4 図に 示すまず推進㓮流量, 総放電電流, 電極長を与え る. 次に $B^{*}$ を仮定する，磁束密度は電流密度の積分 值に比例するので， $B^{*}$ を仮定することは， $\hat{j}$ を仮定 することと同值てある．さらに中性粒子との相互作用 項を 0 とおいて計算を始める，音速点における特異点 条件より $E$ を决定し，エネルギーの钓合式より $T_{\mathrm{p}}{ }^{*}$ を、 $u_{\mathrm{p}}=0$ となる点における特異点条件より $\alpha^{*}$ を計 算する。これらの值を用いて，音速点より上流域の計 算を行い。その結果，積分して得られた中性粒子との 相互作用項が，仮定したものと等しくなるまで計算を 絽り返す 次にこの $T_{\mathrm{p}}{ }^{*}, \alpha^{*}$ を出発值として音速点か ら出口に向かって計算を行い. 得られた電極長が最初 に与えた電極長と等しくなる様に， $B^{*}$ を変化させて さらに絽り返し計算を行う。このように $\dot{m}, J, L の 3$ つの量を与えるだけで，音速点での物理量を決定し， 放電室内の各量の分布を得ることができる．

\section{4. 計算結果}

計算条件を具体的に示す．総放電電流量 $10 \mathrm{kA}$ ，電 極長 $3.3 \mathrm{~cm}$, 電極幅 $6 \pi \mathrm{cm}$, 電極間距離 $2 \mathrm{~cm}$ とし, 中性粒子の温度を $300 \mathrm{~K}$ ，速度を音速に等しいと与え た。

4.1 音速点における物理量 以上の条件下で流量 を変化させて計算を行った。その結果を第 5 図に示 す 図中の $B_{1}$ は，電極入口での磁束密度を表し， $B_{1}$ $=\mu_{0} J$ である. 従って $1-B^{*} / B_{1}$ は，全放電電流のう ち，音速点よりも上流に流れる電流の割合 $j / J に$ 等 しい. 図からわかるように，推進刜流量の増加に伴っ

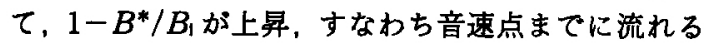
電流量が増加し，同時に $\alpha^{*}$ も増加する。しかし、こ れは流量が大きいほど電離過程が速く進むことを意味

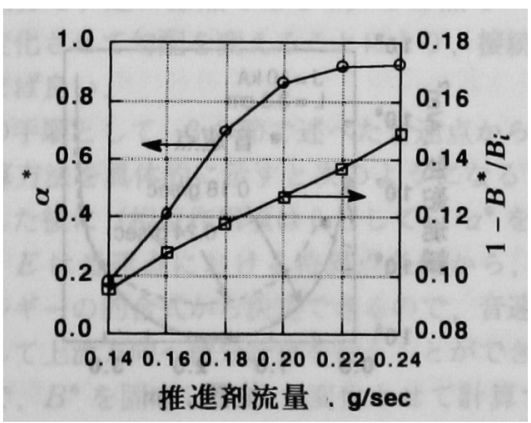

第 5 図 音速点における電離度と磁束密度 
しているわけではない. 理由は後に示すように，流量 の増加に伴い音速点位置が下流に移動するからであ る. 垔音速域でのローレンツカは, 流れを減速する方 向に作用するのて，音速点上流域に流れる電流量の増 加は最終排気速度の減少につながり，効率の低下をも たらす

推進剤流量を $0.14 \mathrm{~g} / \mathrm{s}$ よりも小さくすると, 逆起 電力 $u_{\mathrm{p}} B$ が大きくなりすぎて，この電極長で $10 \mathrm{kA}$ の電流を流しきることができなくなる。これは MPD のオンセット現象に対応していると考えられる ${ }^{1,4}$.

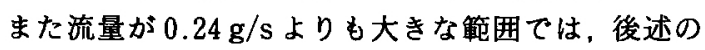
マッ八数分布にみられるように, 電極出口付近の電流 集中によって流れが垔音速に落ちてしまい, 出口まで 解くことができない，これは電極内の流れが全体に亜 音速となるような, 低比推力モードの作動に移ること を表すのではないかと考えられる。

4.2 各物理量の分布 次に放電室内の各物理量の 分布を示す. 推進剂流量が $0.18 \mathrm{~g} / \mathrm{s}$ と， $0.24 \mathrm{~g} / \mathrm{s}$ の 2 つの場合を選び, 流量の違いによる流れ場の変化を 調べる。まず，第6 図に電離度分布を示す，低流量の 方が, 電離度の上昇が急激で, 電離過程の進み方が速 いこれは電極入口における電離度が大きいためであ る. 計算された電極入口の電離度は, $\dot{m}=0.18 \mathrm{~g} / \mathrm{s}$

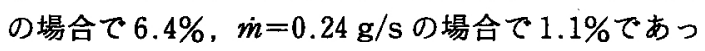
た。

第 7 図に電流密度分布を示す．音速点付近で電流密

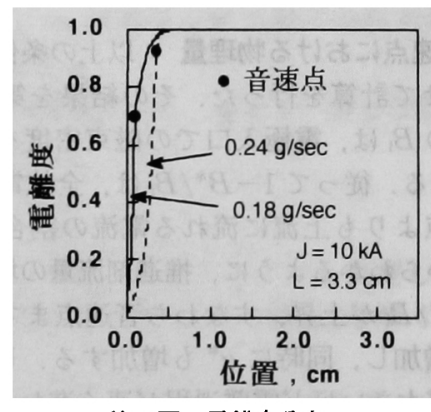

第 6 図電離度分布

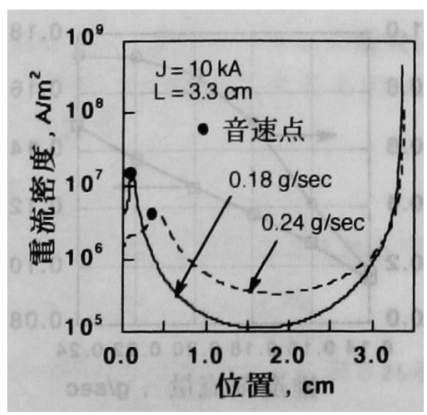

第 7 図電流密度分布
度が函大值を持っているのがわかる．また，低流量の 方が電極中央に流れる電流が小さい，これは前述の様 に，放電電圧に対して逆起電力の割合が大きくなるた めである、ちなみに, $\dot{m}=0.18 \mathrm{~g} / \mathrm{s}$ の場合, 放電電 压は $20.0 \mathrm{~V}$ となる。

第 8 図にマッ八数分布を示す、マッ八数は，音速点 付近の電流が集中する場所で大きく増加しており，そ の後方ではほとんど変化していない，このことは，音 速点付近の詳しい解析が, 推進機の性能評価をする上 で大切であるということを示している．電極終端でマ ッ八数が低下するのは, ジュール加熱により温度が上 昇し、音速が大きくなるためである。

第 9 図に荷電粒子の速度分布を示す. 低流量の方が 加速が大きいが，これは主に単位流量当りの入力電力 の違いに起因している. また電極入口付近において, 僅かではあるが速度が負の領域が存在しており, 荷電 粒子の逆流を示している.この荷電粒子逆流領域の存 在は, 本解析モデルの最も重要な点の 1 つであり, 電 極入口で電離度が高くなるメカニズムでもある．

第 10 図に荷電粒子の温度分布を示す低流量の方 が，全体的に温度は高くなっている．入口にみられる 谷の部分は，この領域で急速に進む電離反応によるも のである．電極終端で温度が非常に大きくなっている が、これは熱伝導を考虑していないためであり，実際 にこのような高温になることはないと考えられる。

続いて速度分布図にみられた負速度領域，すなわち

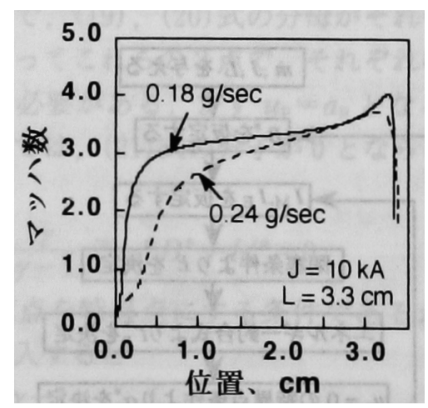

第 8 図 マッハ数分布

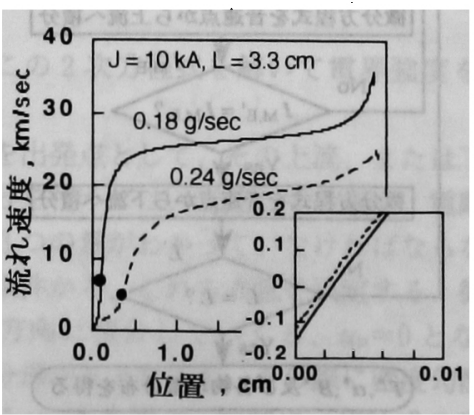

第 9 図荷電粒子の速度分布 


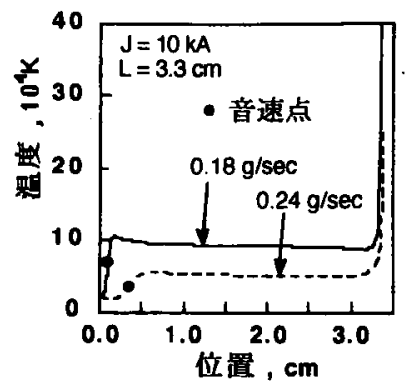

第 10 図 荷電粒子の温度分布

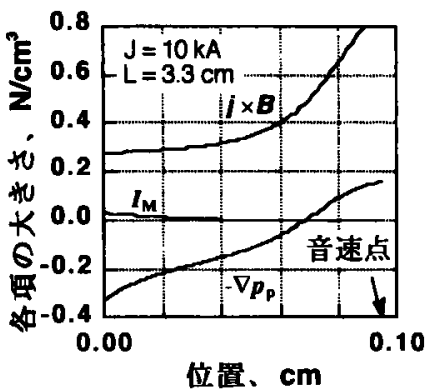

第 11 図運動方程式 (6)の各項の比較

荷電粒子が上流へ逆流する領域について詳しく調へ る.第 11 図に，荷電粒子の運動方程式 (6)の右辺各 項の大きさを比較する．この領域では，ローレンツカ よりも王力勾配による力の方が絶対值が大きく，全体 として負方向に力が㗢いていることがわかる。つまり 荷電粒子は，急速な電離過程により生じる大きな圧力 勾配によって上流へ加速される，また図からわかるよ うに，中性粒子との相互作用により受ける力は，ロー レンツカや王力勾配による力に比較して小さい これ はMPD 推進機が, 高い放電電流/推進郕流量比で作 動するためである．同様に，エネルギー方程式(12)の 右辺の各項の大きさを比較しても，相互作用の項は小 さく，荷電粒子のエネルギー釣合式て，相互作用の項 を近似的に 0 と仮定することも可能である.

\section{5. 特異点解析}

最後に特異点について解析を行う まず音速点であ るが，この特異点は速度勾配 $d u_{\mathrm{p}} / d x$ の式中に現れる ので, 分子, 分母を $x$ と $u_{\mathrm{p}}$ の関数とみなし, 特異点 のまわりにテイラー展開して1次の項まてとる。

$$
\begin{aligned}
\frac{d u_{\mathrm{p}}}{d x} & =\frac{j E-\{\gamma /(\gamma-1)\} j u_{\mathrm{p}} B+I_{\mathrm{E}}{ }^{\prime}}{\{2 \gamma /(\gamma-1)\} n_{\mathrm{p}} k T_{\mathrm{p}}\left(1-u_{\mathrm{p}}{ }^{2} / a_{\mathrm{p}}{ }^{2}\right)} \\
& =\frac{f\left(x, u_{\mathrm{p}}\right)}{g\left(x, u_{\mathrm{p}}\right)} \\
& =\frac{a\left(x-x^{*}\right)+b\left(u_{\mathrm{p}}-u_{\mathrm{p}}{ }^{*}\right)}{c\left(x-x^{*}\right)+d\left(u_{\mathrm{p}}-u_{\mathrm{p}}{ }^{*}\right)}
\end{aligned}
$$

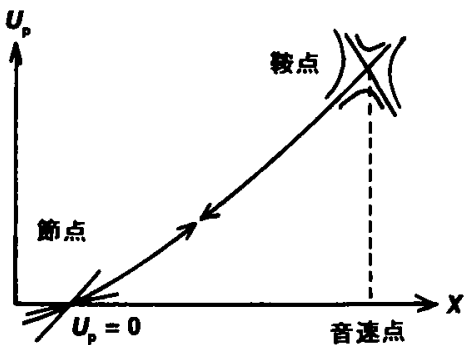

第 12 図 2 流体モデルに生しる特異点と解の接続

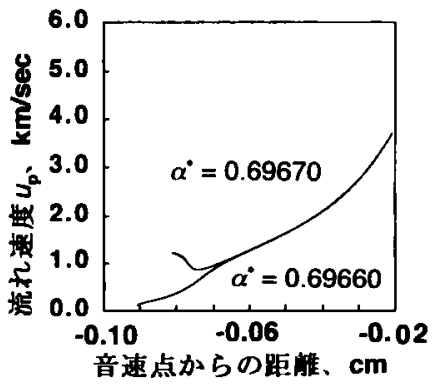

第 13 図 特異点付近での解の分岐

ここで係数 $a, b, c, d$ は以下の様な特異点における量 である。

$$
\begin{array}{ll}
a=f_{x}\left(x^{*}, u_{\mathrm{p}}{ }^{*}\right), & b=f_{u_{\mathrm{p}}}\left(x^{*}, u_{\mathrm{p}}{ }^{*}\right) \\
c=g_{x}\left(x^{*}, u_{\mathrm{p}}{ }^{*}\right), & d=g_{u_{\mathrm{p}}}\left(x^{*}, u_{\mathrm{p}}{ }^{*}\right)
\end{array}
$$

音速点においてこれらの係数の值を計算すると，係数 の間に次のような関係が成り立つ.

$$
(a-d)^{2}+4 b c>0, a d-b c<0
$$

これより音速点は鞍点であることがわかる． $u_{\mathrm{p}}=0$ の 点もまったく同様にして次のような関係式が成立する のでこの点は節点であることがわかる．

$$
(a-d)^{2}+4 b c>0, \quad a d-b c>0
$$

流れ場中に特異点が 2 つ存在するために，解を得るに は両側の特異点から計算を行い，その間で解を接続す る必要がある．特異点の性質から考えると，第 12 図 に示すように音速点は鞁点であるので，この特異点を 通る解は 2 つり，このうちの 1 つの解を用いて途中 まで積分し，逆に節点である $u_{\mathrm{p}}=0$ の点でパラメー 夕を変化させて勾配を変えることにより，接続する解 を探せば良い。

その手順として，3.2 節で述へた音速点から上流へ の計算方法を具体的に示すと次のようになる： $B^{*}$ を 仮定した後に（相互作用項は 0 として）， $\alpha^{*}$ を仮定す れば，Eは音速点における特異点条件から， $T_{\mathrm{p}}{ }^{*}$ は エネルギーの釣合式から決定できるので, 音速点から 出発して上流方向へ積分計算を行うことができる．と ころで， $B^{*}$ を固定し， $\alpha^{*}$ を変化させて計算すると， 第 13 図に示すように，ある $\alpha^{*}$ を境にして分布が大 
きく分かれる。この分岐は $u_{\mathrm{p}}=0$ の点が特異点であ ることによる。そして $u_{\mathrm{p}}=0$ の点での特異点条件 （26）式を満足する解は，この $\alpha^{*}$ の付近に存在すると 予想される．そこで，音速点から上流方向に分岐する 手前まで積分し，逆に $u_{p}=0$ の点から，(26)式を満 たすようにパラメーターを変化ざせて下流方向に計算 を行い，解を接続する， $u_{\mathrm{p}}=0$ の点から計算を開始す るためには $B^{0}, \alpha^{0}, T_{\mathrm{p}}^{0}$ の 3 つが出発値として必要で あるが，このうちの1つ，例えば $T_{\mathrm{P}}^{0}$ が(26)式から決 定されるとすれば， $B^{0}$ と $\alpha^{0}$ のつを仮定すればよ

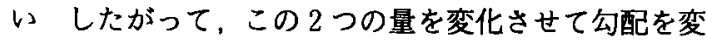
えることにより，接続し得る解を探せば良い

\section{6. ま め}

本研究では，非平衡かつ 2 流体のモデルを導入し， 流れ場の解析を行った．得られた結果をまとめると以 下のようになる：

1. 推進戍流量, 総放電電流量, 電極長の 3 パラメ 一ターから，全物理量分布を決定することがで きた。

2. 推進剤流量が小さいほど非平衡電離過程が速く 進み，その結果電流分布は入口に集中すること がわかった。

3. 電極入口付近には, 荷電粒子の負速度領域が存 在し，フラススマが上流方向に逆流していること がわかった。

4. 電極入口における電離度とプラズマ温度は，立 $=0.18 \mathrm{~g} / \mathrm{s}$ の場合でそれぞれ $6.4 \%, 23800 \mathrm{~K}$, $\dot{m}=0.24 \mathrm{~g} / \mathrm{s}$ の場合で $1.1 \%, 22500 \mathrm{~K}$ となっ
た。

5. 2 流体モデルの流れ場には 2 つの特異点が存在 し，特異点の解析により，音速点は鞍点， $u_{\mathrm{p}}=$ 0 となる点は節点となることがわかった．

\section{参考文献}

1) Lawless, J.L. and Subramanian, V.V.: Theory of Onset in Magnetoplasmadynamic Thrusters, J. Propulsion and Power, 3, 2 (1987), pp. 121-127.

2) Kuriki, K. and Nakayama, T.: Magnetosonic Condition in Magnetoplasmadynamic Flow, J. Propulsion and Power, 8, 6 (1992), pp. 1208-1211.

3) Tahara, H., Kagaya, Y. and Yoshikawa, T.: Current Distributions in a Quasisteady Magnetoplasmadynamic Arcjet, J. Propulsion and Power, 9, 5 (1993), pp. 778-779.

4) Subramanian, V.V. and Lawless, J.L.: Onset in Magnetoplasmadynamic Thrusters with Finite-Rate Ionization, J. Propulsion and Power, 4, 6 (1988), pp. 526532

5) Sumida, T. and Toki, K. Real-Gas Effect on the Magnetoplasmadynamic Arcjet, J. Propulsion and Power, 7, 6 (1991), pp. 1072-1074.

6) Shoji, T. and Kimura, I.: Thermal and Ionization Non equilibrium in Magnetoplasmadynamic Flows, Trans Jpn. Soc. Aero. Space Sci., 35, 109 (1992), pp. 108-118.

7) Burton, R.L. and Tiliakos, N. : Injected Propellant Ionization in MPD Thrusters, J. Propulsion and Power, 9, 5 (1993), pp. 764-770.

8) Sheppard, E. and Martinez-Sanchez, M.: Ionization Rate Models and Inlet Ignition in Self-Field MPD Thrusters, International Electric Propulsion Conference, IEPC-93-071 (1993).

9) Choueiri, E.Y. and Okuda, H. : Anomalous Ionization in the MPD Thruster, International Electric Propulsion Conference, IEPC-93-067 (1993).

10) Spitzer, L., Jr.: Physics of Fully Ionized Gases, 2nd ed., Interscience Publishers, New York, 1962. 